\title{
Konsep Dan Perkembangan Pemikiran Tentang Tanggung Jawab Sosial Perusahaan
}

\author{
Oleh : Erman Rajagukguk \\ Guru Besar Fakultas Hukum UI Jakarta \\ e-mail:
}

\begin{abstract}
The legal framework pertinent to Indonesian companies has assigned the companies to accomplish what so called by Corporate Social Responsibility (CSR). While in its wider concept CSR encompasses human rights, labor, consumers protection and environment, in its simpler concept, it is translated as the welfare development of the concerned surrounding community.
\end{abstract}

Keywords: Tanggung jawab sosial perusahaan, globalisasi

\section{Pendahuluan}

Diskusi yang pertama tentang apakah perusahaan mempunyai tanggung jawab sosial terjadi pada tahun 1930-an di Amerika Serikat. Saat itulah istilah tanggung jawab perusahaan atau Corporate Social Responsibility (CSR) lahir. Merrick Dodd menyatakan, bahwa perusahaanperusahaan besar mempunyai tanggung jawab kepada masyarakat karena perusahaan-perusahaan tersebut mempunyai kekuatan atau kekuasaan yang besar. Sebaliknya Adolf Berle menyatakan, bahwa perusahaan itu adalah milik para pemegang sahamnya dan oleh karena itu harus mengikuti kebutuhan-kebutuhan mereka saja. Posisi yang dominan pada waktu itu menolak corporate social resposibility yang tercermin dalam undang-undang perusahaan di Amerika Serikat, yang lebih berpihak terhadap kepentingan para pemegang saham. Setiap keputusan perusahaan ada di tangan para pemegang saham.

Para akademisi Amerika pada waktu itu percaya bahwa kepentingankepentingan lain tidak menjadi perhitungan. Keutamaan shareholder ditentang oleh pandangan yang menganut stakeholder theory. Teori 
pemangku kepentingan tersebut mendorong ide bahwa perusahaan juga harus memperhitungkan kepentingan-kepentingan dari stakeholder lainnya disamping pemegang saham. Konsep ini berkembang di Jepang sebagaimana juga di sebagian besar negara-negara Eropa.

Bertahun-tahun kemudian terjadi berbagai gelombang diskusi mengenai tanggung jawab perusahaan, namun konsep tersebut masih menunggu terobosan terakhir. Dapat dikatakan pandangan yang lebih terbuka terhadap tanggung jawab sosial lebih besar di Eropa daripada di Amerika Serikat. Tetapi ada kesadaran yang terus berkembang tentang perlunya tanggung jawab sosial perusahaan tersebut di Amerika Serikat.

\section{Era Globalisasi Mendukung Corporate Social Responsibility}

Perdebatan tentang corporate social responsibility dimulai kembali dengan terbukanya skandal bangkrutnya Enron dan perusahaanperusahaan lainnya di Amerika. Dalam konteks tingkah laku yang menyimpang dari perusahaan dan berakhir dengan jatuhnya perusahaanperusahaan tersebut, seluruh sistem dari pengelolaan perusahaan, dari kerangka pengaturan sampai dengan dasar-dasar moral, menjadi suatu pertanyaan besar dalam proses tersebut. Adanya tanggung jawab sosial perusahaan mendapat dukungan.

Amerika Serikat mulai menyadari bahwa sistem yang sekarang ini tidak sempurna. Peraturan-peraturan baru dikeluarkan yang intinya pengaturan yang ketat untuk mencegah skandal yang sama terulang lagi di masa yang akan datang. Namun demikian Amerika Serikat tetap pada prinsipnya dan tidak melaksanakan peraturan-peraturan apapun juga yang berkenaan dengan masalah-masalah sosial.

Konsensus hukum yang predominan mengenai tanggung jawab sosial perusahaan di Amerika sekarang ini tidak berubah dari pandangan Adolf Berle beberapa tahun yang lalu. Perusahaan tidak mempunyai tanggung jawab sosial yang spesifik melebihi maksimalisasi keuntungan. Sebaliknya negara yang harus mempunyai perhatian mengenai kesejahteraan sosial dari rakyatnya. Namun, bagaimanapun juga seseorang berpihak kepada pendekatan masa lalu atau tidak, dapat dikatakan dengan pasti bahwa solusi ini tidak lagi berlaku dalam konteks ekonomi pada abad 21 ini, dimana globalisasi telah merubah fokus.

Berdasarkan premisis, negara dapat membiayai proyek-proyek kemasyarakatan dengan menggunakan sumber-sumber keuangan yang 
dibayar oleh perusahaan-perusahaan melalui pajak. Pendekatan ini dapat digunakan sepanjang perusahaan tersebut hanya berhubungan dengan negara-negara yang sama dimana mereka membayar pajak. Hal itu mensyaratkan bahwa negara yang sama mengatasi kelemahan sosial dan mendapatkan pemasukan dari pajak. Namun, dalam gambaran ekonomi abad 21 ini, batas-batas nasional suatu negara hilang pentingnya. Perusahaan-perusahaan multinasional bergerak di dalam pasar-pasar yang berbeda, sebagian besar mempunyai anak-anak perusahaan di berbagai negara yang berbeda. Akibatnya, uang yang diperoleh perusahaan tersebut di beberapa negara tertentu tidak selalu tinggal di negara tersebut. Dengan demikian, tidak ada penerimaan pajak oleh negara yang dapat dipergunakan untuk menolong kelemahan sosial. Lagi pula, peraturan pajak yang modern dan teknik akuntansi yang "progessif" memungkinkan perusahaan-perusahaan mengurangi utang pajak mereka dengan akuntansi silang antara negara-negara dan anak-anak perusahaan. Sebagai akibatnya banyak perusahaan-perusahaan yang mempunyai pendapatan kotor triliunan dollar dalam kenyataannya dalam membayar pajak sangat kecil. Oleh karenanya pendapat yang mengatakan bahwa bekerja dengan baik yaitu artinya, semata-mata memaksimalkan kesejahteraan pemegang saham harus dirubah dalam era globalisasi ini.

Sebagaimana terlihat di atas dalam era globalisasi saat ini kekuatan negara bangsa (national state) berkurang. Selanjutnya negara kehilangan kemampuannya untuk mendukung mengatasi kelemahan sosial. Pertanyaan yang muncul adalah siapa yang menggantikannya. Kekuatan bergeser kepada perusahaan-perusahaan multinasional. Banyak diantara mereka mempunyai pendapatan kotor lebih besar dari pendapatan negaranegara berkembang. Pengaruhnya yang amat besar dalam keputusankeputusan politik tidak dapat ditolak. Globalisasi telah menyediakan mereka kesempatan untuk memperbaiki keuntungan dan menolong mereka mengambilalih negara bangsa pada abad ke 21 ini. Akibatnya, perusahan-perusahaan ini harus memikul tanggung jawab sosial yang semula ada di tangan negara. ${ }^{1}$

${ }^{1}$ Oliver Krackhardt, “Beyond the Neem Tree Conflict: Questions of Corporate Behavior in a Globalised World", 21 New Zealand University Law Review 347, Juni 2005. 


\section{Tanggung Jawab Sosial Perusahaan di Eropa}

The European Union (EU) dan perusahaan-perusahaan yang berbasis di sana merupakan front terdepan dalam pengambilan inisiatif untuk adanya corporate social responsibility. Pertama, "The Green Paper on Promoting a European Framework for Corporate Social Responsibility 2001". Paper ini berisi konsep dari tanggung jawab sosial perusahaan dari dimensi internal maupun eksternal dan menyajikan pandangan yang holistik. Perusahaan dapat mempunyai dan memelihara keuntungan konpetitif terhadap pesaingnya dengan mempraktekkan tanggung jawab sosial perusahaan.

Tanggung jawab sosial perusahaan harus dianggap investasi dan bukan sebagai ongkos. Lima tahun kemudian pada 22 Maret 2006 EC meluncurkan "European Alliance for Corporate Social Responsibility". Aliansi terbuka, sukarela dan menjadi payung politik untuk inisiatif tanggung jawab sosial yang baru atau yang telah ada oleh perusahaan-perusahaan dan pemangku kepentingan mereka. Walaupun EC memakai pendekatan sukarela yang lebih efektif dan kurang birokratis, ide ini mendapat kritik yang tajam karena mengurangi retorika dan secara total menolak opsi untuk suatu peraturan hukum atau monitoring yang independen terhadap tingkah laku yang menyimpang dari perusahaan. Pendekatan tersebut merupakan kemenangan kaum bisnis dan kekalahan Lembaga Swadaya Masyarakat (LSM).

Inisiatif lain adalah berkaitan dengan "the Eco-label and Eco-Management and Audit Scheme (EMAS)". Skema ini terbuka bagi perusahaanperushaaan sejak 1995, namun hanya membatasi perusahaan-perusahaan di sektor industri. Tetapi sejak tahun 2001 termasuk perusahaan publik dan privat dapat ikut juga dalam program ini. EMAS telah menyebabkan perusahaan-perusahaan dan departemen pemerintah dalam kegiatankegiatannya lebih memperhatikan lingkungan hidup, yaitu dengan meminimalkan sampah, mengurangi konsumsi energi, menciptakan pemakaian yang efisien dari sumber alam.

Disamping itu pada 21 Juni 1976 lahir "The OECD Guidelines for Multinational Enterprises (MNEs)" yang merupakan bagian dari "The Declaration on International Investment and Multinational Enterprises". Pedoman ini mencakup bidang-bidang hak azasi manusia, prinsip keterbukaan, tenaga kerja dan hubungan industrial, lingkungan hidup, perang terhadap penyuapan, kepentingan konsumen, ilmu dan teknologi, persaingan usaha, serta perpajakan. 
Kemudian lahir pula ILO Declaration tahun 1977. Pada tahun 2000 ILO Declaration diperbaiki yang berisi prinsip-prinsip organisasi majikan dan buruh. Deklarasi ILO ini berkaitan dengan ketenagakerjaan, pelatihan, kondisi kerja, dan hubungan industrial. Paragrap 8 dari deklarasi ini adalah berkenaan dengan hak azasi manusia.

Selanjutnya pada 31 Januari 1999 lahir pula di forum ekonomi dunia di Davos apa yang disebut "U.N. Global Compact", yang terdiri dari sembilan prinsip di bidang hak azasi manusia, perburuhan, dan lingkungan hidup. Pada 24 Juni 2004 pada waktu berlangsungnya "Global Compact Leaders Summit", prinsip tersebut ditambah dengan anti korupsi. Akhirnya termasuk tanggung jawab sosial perusahaan adalah hal-hal yang berhubungan dengan hak azasi manusia sebagaimana yang tercantum dalam "The U.N. Norms on the Responsibility of Transnational Corporation and other Business Enterprises". ${ }^{2}$

\section{Perbedaan antara Corporate Philanthropy dan Corporate Social Respon- sibility}

Terdapat dua pertanyaan dasar mengenai tanggung jawab sosial perusahaan. Pertama, mengapa hari ini kita berbicara menekankan perlunya tanggung jawab perusahaan yang sebelumnya tidak dikenal 15 atau 20 tahun yang lalu? Pertanyaan kedua adalah, apa jawaban yang diberikan sekarang mengenai perlunya tanggung jawab sosial perusahaan yang berkembang dalam perdebatan budaya dan perdebatan akademik?

Pertama-tama, harus diklarifikasi banyaknya kebingungan, masyarakat cenderung mencampuradukan corporate social responsibility dengan konsep yang lebih tua, yaitu corporate philanthropy. Keduanya merupakan sesuatu yang sangat berbeda. Corporate philanthropy bukanlah pengaturan yang baru. Sejak berkembangnya masyarakat kapitalis, corporate philanthropy selalu ada. Ide di belakang corporate philanthropy adalah aliansi antara untuk keuntungan dan bukan untuk keuntungan, dimana modal dapat digunakan untuk keuntungan dari organisasi yang tidak mencari keuntungan. Dengan demikian, suatu perusahaan dapat mengaitkan dirinya pada corporate philanthropy dan tidak bertanggung

\footnotetext{
${ }^{2}$ Surya Deva, "Sustainable Good Governance and Corporation: An Analysis of Asymmetries", Georgetown International Environmental Law Review, Summer, 2006, hal. 735 - 740 .
} 
jawab sosial. Fakta menunjukkan bahwa, sementara logika perusahaan philanthropic salah satu dari konsensi atau perasaan belas kasihan, corporate social responsibility bersandar kepada prinsip kesamaan martabat dari semua subjek yang terlibat dalam kegiatan perusahaan, dari penyusunan tujuan-tujuan sampai kepada memenuhi rencana entrepreneur. Dengan perkataan lain, dapat dikatakan pemimpin bisnis selalu menyadari bahwa untuk dapat menjamin kondisi hidup pekerja yang lebih baik, artinya mendorong mereka mempunyai loyalitas dan identifikasi dengan tujuantujuan perusahaan. Begitu juga perhatian yang sama kepada stakeholder yang lainnya. ${ }^{3}$

\section{Ruang Lingkup Tanggung Jawab Sosial Perusahaan}

Istilah "tanggung jawab" dan "sosial" juga seringkali disalahartikan. Sebagai contoh, kata "sosial" mengacu kepada masalah seperti kesehatan, pendidikan, keamanan dan lain sebagainya-yang pada umumnya menjadi tanggung jawab pemerintah. Yang lain mendefinisikan "sosial" mengacu kepada masalah planet dan lingkungan. Sedangkan kata "tanggung jawab" adalah tanggung jawab perusahaan atas tindakannya kepada masyarakat.

Dalam hal tindakan apa saja, sebagian orang menafsirkan istilah tersebut di atas adalah perusahaan bertanggung jawab untuk melakukan sesuatu atas masalah yang berdampak kepada masyarakat; yang lain menafsirkan bahwa perusahaan bertanggung jawab atas segala kegiatannya yang berdampak kepada masyarakat. Dua pandangan ini memiliki implikasi yang berbeda.

Pada cara pandang yang pertama, perusahaan bertanggung jawab di luar tujuan perusahaan, seperti turut bertanggung jawab atas kesejahteraan masyarakat. Banyak dari kegiatan ini menjadi tanggung jawab dari penduduk itu sendiri dan pemerintah mereka. Percuma saja dikatakan, sebagian besar perwakilan sektor privat tidak setuju dengan fungsi perusahaan yang demikian dan menolak konsep CSR. Pada kasus kedua, perusahaan adalah legal person yang bertanggung jawab atas

\footnotetext{
${ }^{3}$ Stefano Zamagni and Henry Schawalbenberg, "Religious Values and Corporate Decision Making: An Economist's Perspective", Fordham Journal of Corporate and Financial Law, 2006, hal 575 - 576.
} 
dampak dari kegiatannya, dan kegiatannya ini harus dijalankan dengan menghormati mereka yang terkena dampaknya.

Ada perbedaan yang cukup signifikan apa yang dimaksud dengan bertanggung jawab atas kegiatan perusahaan. Konsep tanggung jawab berubah dari kontek ke kontek, dari budaya ke budaya, dalam kontek dan budaya, perubahan yang terjadi dari waktu ke waktu.

Beberapa tahun yang lalu, masyarakat tidak mempertimbangkan perusahaan makanan bertanggung jawab atas obesitas yang dialami konsumen. Ini menjadi masalah genetis, beberapa tanggung jawab ditujukan kepada produsen makanan dan beberapa diantaranya bereaksi dengan memproduksi makanan sehat dan mendidik konsumen. Tak ada yanga menklaim bahwa perusahaan makanan cepat saji di negara-negara maju berpikir bahwa pengabaian masalah-masalah tersebut tidak berpengaruh pada garis dasar. Saat ini, setiap orang setuju bahwa perusahaan farmasi harus menghasilkan obat yang menyembuhkan penyakit yang tertera dalam resep obat, namun tidak semua orang setuju bahwa ini adalah tanggung jawab perusahaan farmasi untuk memproduksi obat murah bagi orang miskin. Pada beberapa kontek, adalah bijak bagi perusahaan untuk bertanggung jawab kepada konsumen yang bereaksi secara positif, maka hal ini akan meningkatkan reputasi perusahaan dan adanya pengakuan dari konsumen, yang mana akan meningkatkan daya saing perusahaan.

Akibat dari kegiatan perusahaan tidak terdefinisikan dengan baik, sehingga masih terdapat kebingungan antara stakeholder atas tanggung jawab perusahaan. Lebih jauh, banyak dari para stakeholder yang meminta, atau bertindak seolah-olah perusahaan bertanggung jawab atas tindakan, walaupun perusahaan menganggap tindakan ini di luar tanggung jawabnya. Perusahaan dapat menklaim bahwa ini bukan masalahnya, namun dengan mengabaikan permintaan ini dapat merugikan perusahaan. Pertimbangan ini menunjukan bahwa walaupun di luar pengertian CSR, di mana perusahaan bertanggung jawab atas dampak dari kegiatannya, masih terdapat sejumlah kontroversi. ${ }^{4}$

Dengan demikian, sebenarnya konsep tanggung jawab sosial perusahaan mencakup kepatuhan perusahaan kepada perlindungan

${ }^{4}$ Antonio Vives, "Corporate Social Responsibility: The Role of Law and the Markets and the Case of Developing Countries," 83 Chicago-Kent Law Review 199, 2008, hal. $200-202$. 
buruh, perlindungan lingkungan hidup, perlindungan konsumen, dan perlidungan hak azasi manusia secara keseluruhan.

Pertama, tanggung jawab sosial perusahaan antara lain selalu dikaitkan dengan kepentingan pemegang saham versus pemangku kepentingan (stakeholder) dalam kaitannya dengan perlindungan tenaga kerja. Di Amerika, umpamanya, sejumlah perusahaan yang berbasis di negara tersebut mendapatkan kesan yang negatif dalam kaitannya dengan ketenagakerjaan. Mereka selalu dikaitkan mengontrakkan pekerjaan ke negara-negara dimana standar perburuhannya tidak diakui. Menghadapi hal tersebut menjawabnya dengan program-program tanggung jawab sosial perusahaan, sebagian berhasil, sebagian mengalami kegagalan. Pertama, banyak dari corporate codes of conduct tidak mempunyai kredibilitas. Sebagian dari corporate codes of conduct adalah inisiatif, formulasi atau rumusan dan diselesaikan administrator di tingkat tinggi perusahaan. Dengan demikian tidak menerima masukan dari mereka yang harusnya mendapat manfaat. Kedua, corporate codes of conduct seringkali tidak berisi substansi yang nyata dan gagal menempatkan unsur-unsur yang vital untuk implementasi dan penegakkannya. Kritik datang dari kaum pekerja. Sebagai jawaban dari penggunaan codes of conduct tersebut beberapa wakil dari organisasi buruh menyusun apa yang dikenal sebagai International Framework Agreements (IFAs)" . ${ }^{5}$

Globalisasi dapat diartikan sebagai integrasi kegiatan ekonomi melalui pasar. Kekuatan yang mendorongnya adalah kemajuan teknologi dan perubahan kebijakan. Bertambah murahnya kegiatan transportasi dan komunikasi menyebabkan ketergantungan yang makin membesar kepada kekuatan pasar. Walaupun pengertian globalisasi terbatas kepada wacana ekonomi, kontroversi mengenai globalisasi selalu berujung kepada akibat sosialnya. Berkembangnya jaringan pemasokan global menunjukkan contoh yang tipikal dari integrasi ekonomi yang disertai dengan akibatakibat sosial.

Dengan bertambah besar berkurangnya biaya transportasi dan dengan bantuan perjanjian perdagangan internasional, barang-barang dapat diproduksi di tempat-tempat yang mempunyai competitive advantages dan

${ }^{5}$ Owen E. Herrnstadt, "Are International Framework Agreements a Path to Corporate Social Responsibility", University of Pennsylvania Journal of Business and Employment Law, Fall 2007, hal 187. 
dapat dijual di seluruh dunia "melalui sistem produksi dan distribusi yang kompleks berdasarkan berbagai pengaturan hukum yang terorganisasi". Untuk meningkatkan keunggulan kompetitif dari lokasi produksi barang tertentu, perusahaan asing tidak harus mendirikan fasilitasnya di tempat tersebut. Penanaman modal langsung di suatu negara yang tidak familiar budaya dan lingkungan bisnisnya adalah memakan ongkos. Melakukan kontrak dengan pabrik lokal, perusahaan asing dapat memanfaatkan sumber-sumber di negara bersangkutan tanpa mengalami kesakitan dan mempunyai resiko yang terkait dengan penanaman modal. Inilah yang dilakukan oleh perusahaan multinasional, seperti NIKE dan yang lainnya di era integrasi ekonomi. Mereka mengontrak jaringan pasokan yang beroperasi di negara-negara berkembang untuk memproduksi barang dengan harga yang bersaing dan menjual barang tersebut ke pasar seluruh dunia, sebagian besar negara-negara maju.

Tipe strategi bisnis semacam ini melahirkan implikasi hukum yang penting. Pertama, tanpa mengawasi secara langsung pabrik dan menggaji buruh di negara produsen, perusahaan asing tidak mendapat hambatan dari peraturan lingkungan hidup dan peraturan perlindungan buruh di negara yang bersangkutan. Kedua, walaupun ada argumen bahwa perusahaan asing tersebut terikat kepada undang-undang di negara mereka berkenaan bisnis mereka di luar negeri, pengalaman Amerika menunjukkan pendekatan itu tidak efektif. Ketiga, perusahaan multinasional tidak mendapat hambatan dari hukum internasional pula, karena mereka tidak merupakan badan hukum internasional. Walaupun ada beberapa instrumen hukum internasional yang menyertai perusahaan mutinasional memiliki kewajiban kepada masyarakat, deklarasi itu tidak mengikat, tidak ada penegakkannya dan mekanisme monitoring.

Pemasok dari negara-negara berkembang yang melakukan kontrak dengan perusahaan mutinasional biasanya perusahaan skala kecil menurut ukuran global. Pabrik-pabrik kecil ini mendapat keuntungan dari strategi pengurangan ongkos. Perusahaan-perusahaan negara berkembang tidak mendapat keuntungan dari menjual pengetahuan baru, tetapi dari menjual upah murah. Perusahaan-perusahaan ini untuk dapat bersaing dan memperoleh keuntungan tidak banyak memperhatikan kesejahteraan buruh.

Perkembangan menarik di Cina, yang disebut-sebut sebagai "the World's Factory" adalah lahirnya corporate social responsibility dalam Undang-Undang Perusahaan 2006. 
"Compliance with law is the core content of corporate social accountability standards. The specificity of law can provide clear guidelines for compliance and enforcement and more harmonized standards. Accordingly, how to improve the protection offered by labor laws has always been a focus in discussion about corporate social responsibility in China. In the recent years, the Chinese government has promulgated many laws and rules on labor protection; for example, labor unemployment insurance, prohibition of child labor, minimum wages, and collective employment contracts. However, the effectiveness of these new laws and the enforcement of them by the government need to be examined closely." 6

Kedua, tanggung jawab sosial perusahaan selalu dikaitkan dengan perlindungan lingkungan hidup. Tanggung jawab sosial perusahaan diartikan sebagai seperangkat kebijakan yang komprehensif, praktek dan program yang terintegrasi dalam kegiatan bisnis, jaringan pemasok dan proses pengambilan keputusan di seluruh perusahaan dimanapun perusahaan itu menjalankan kegiatannya, dan termasuk tanggung jawab terhadap tindakan-tindakan yang diambil pada masa lalu dan sekarang, dan implikasinya di masa depan. Salah satu yang membuat masyarakat khawatir adalah pencemaran lingkungan yang dihasilkan perusahaan. Karena berbagai tekanan dari stakeholder termasuk dari pemerintah dan media massa, perusahaan-perusahaan multinasional menyadari bahwa komitmen kepada tanggung jawab lingkungan dan sosial telah berubah. Paradigma baru mengenai tanggung jawab sosial perusahaan terkait erat dengan tanggung jawab lingkungan. Banyak dari prinsip environmental justice disampaikan pada tingkat pembuatan keputusan mengenai public policy. Sebaliknya, beberapa dari prinsip tersebut diarahkan pada tanggung jawab sektor swasta. Pendekatan memasukkan perlidungan lingkungan hidup kedalam hak-hak azasi manusia dimulai sejak tahun 1972 pada waktu berlangsungnya Konferensi Perserikatan Bangsa-Bangsa tentang "Human Environment".

${ }^{6}$ Li-Wen Lin, "Corporate Social Accountability Standards in the Global Supply Chain: Resistance, Reconsideration, and Resolution in China", Cardozo Journal of International and Comparative Law, Fall 2007, hal. 361.

${ }^{7}$ David Monsma, "Equal Rights, Governance, and the Environment: Integrating Environment Justice Principles in Corporate Social Responsibility", Ecology Law Quarterly, 2006, hal. $475-478$. 
Ketiga, ketika Enron dan Worldcom bangkrut pada 2001 dan 2002 para akademisi, legislator dan pemimpin perusahaan mencoba mencari jalan untuk mencegah kejatuhan perusahaan-perusahaan yang lain. Mereka meneliti praktek-praktek akuntansi, persyaratan keterbukaan keuangan, dan berbagai komponen perusahaan untuk menciptakan undang-undang yang lebih kuat untuk mencegah kegagalan pasar dan korupsi di masa depan. Dalam konteks Enron dan Worldcom, pembahasan kejatuhan kedua perusahaan tersebut berkisar kepada akibat negatif praktek kedua perusahaan tersebut didalam masyarakat dimana mereka beroperasi. Pertanyaannya adalah bersamaan dengan akuntanbilitas perusahaan, dapatkah perusahaan dibebankan juga tanggung jawab sosial perusahaan. Paradigma baru perusahaan dalam kaitannya dengan tanggung jawab perusahaan tidak saja bagaimana memaksimalkan keuntungan pemegang saham dalam jangka pendek, tetapi juga bagaimana keuntungan tersebut mendatangkan manfaat kepada masyarakat dan perusahaan itu sendiri. ${ }^{8}$

\section{Penutup}

Setidak-tidaknya dua Undang-Undang di Indonesia mengamanatkan agar perusahaan melaksanakan tanggung jawab sosial. Pertama, Pasal 15 b Undang-Undang Nomor 25 Tahun 2007 tentang Penanaman Modal menyatakan, bahwa setiap investor berkewajiban melaksanakan tanggung jawab sosial perusahaan. Penjelasan pasal ini menyatakan bahwa yang dimaksud dengan tanggung jawab sosial perusahaan adalah tanggung jawab yang melekat pada perusahaan penanaman modal untuk tetap menciptakan hubungan yang serasi, seimbang, dan sesuai dengan lingkungan, nilai, norma, dan budaya masyarakat.

Setelah itu tanggung jawab sosial perusahaan dicantumkan lagi dalam Undang-Undang Nomor 40 Tahun 2007 tentang Perseroan Terbatas. Pasal 74 ayat (1) Undang-Undang ini menyatakan perseroan yang menjalankan kegiatan usahanya di bidang dan atau berkaitan dengan sumber daya alam wajib melaksanakan tanggung jawab sosial dan lingkungan. Ayat (2) pasal ini manyatakan kewajiban tersebut diperhitungkan sebagai biaya

${ }^{8}$ Niloufar A. Park and Carmen M. Butler, "Mayday Payday: Can Corporate Social Responsibility Save Payday Lenders", Rutgers Journal of Law \& Urban Policy, Fall, 2005, hal. 119. 
perseroan yang pelaksanaannya dilakukan dengan memperhatikan kepatutan dan kewajaran. Selanjutnya ayat (3) menyebutkan perseroan yang tidak melaksanakan kewajiban sebagaimana yang dimaksud ayat (1) dikenai sanksi sesuai dengan peraturan perundang-undangan yang terkait. Kemudian ayat (4) menyatakan ketentuan lebih lanjut mengenai tanggung jawab sosial dan lingkungan diatur dengan Peraturan Pemerintah.

Corporate Social Responsibility dalam konsep yang luas mencakup kepatuhan perusahaan kepada Hak Azasi Manusia, perburuhan, perlindungan konsumen, dan lingkungan hidup. Dalam pengertian yang sempit yaitu pembangunan kesejahteraan masyarakat sekitar perusahaan berada. Sebenarnya jika mengacu kepada tanggung jawab sosial perusahaan dalam arti luas berarti pasal kedua undang-undang tersebut tadi menekankan lagi perlunya perusahaan mematuhi undang-undang yang melindungi masyarakat, antara lain, perlindungan hak azasi manusia, lingkungan hidup, pekerja, dan konsumen. Namun yang ditunggu oleh masyarakat dan pengusaha adalah bagaimana perusahaan ikut mensejahterakan masyarakat sekitarnya. Berbagai perusahaan selama ini telah menjalankan community development dalam bentuk pembangunan fasilitas kesehatan, pendidikan, prasarana jalan, beasiswa, dan bimbingan kepada usaha kecil. Namun sebagian besar perusahaan masih bertanya apa yang dimaksud dengan CSR dalam kedua undang-undang tersebut? Suatu Peraturan Pemerintah sebagaimana diamanatkan oleh UndangUndang Perseroan Terbatas yang baru perlu segera terbit. 


\section{Daftar Pustaka}

Antonio Vives, “Corporate Social Responsibility: The Role of Law and the Markets and the Case of Developing Countries", 83 Chicago-Kent Law Review 199, 2008.

David Monsma, "Equal Rights, Governance, and the Environment: Integrating Environment Justice Principles in Corporate Social Responsibility", Ecology Law Quarterly, 2006.

Li-Wen Lin, "Corporate Social Accountability Standards in the Global Supply Chain: Resistance, Reconsideration, and Resolution in China", Cardozo Journal of International and Comparative Law, Fall 2007.

Niloufar A. Park and Carmen M. Butler, "Mayday Payday: Can Corporate Social Responsibility Save Payday Lenders", Rutgers Journal of Law \& Urban Policy, Fall, 2005.

Oliver Krackhardt, "Beyond the Neem Tree Conflict: Questions of Corporate Behavior in a Globalised World", 21 New Zealand University Law Review 347, Juni 2005.

Owen E. Herrnstadt, "Are International Framework Agreements a Path to Corporate Social Responsibility", University of Pennsylvania Journal of Business and Employment Law, Fall 2007.

Stefano Zamagni and Henry Schawalbenberg, "Religious Values and Corporate Decision Making: An Economist's Perspective", Fordham Journal of Corporate and Financial Law, 2006.

Surya Deva, "Sustainable Good Governance and Corporation: An Analysis of Asymmetries", Georgetown International Environmental Law Review, Summer, 2006.

Undang-Undang Nomor 25 Tahun 2007 tentang Penanaman Modal. Undang-Undang Nomor 40 Tahun 2007 tentang Perseroan Terbatas. 